\title{
Hubungan kecerdasan emosional dan kecerdasan spiritual dengan indeks prestasi mahasiswa program studi kebidanan
}

\author{
Legina Anggraeni ${ }^{*}$, Dinni Randayani Lubis ${ }^{2}$ \\ 1,2 Universitas Binawan
}

\section{INFORMASI ARTIKEL:}

\begin{tabular}{l}
\hline Riwayat Artikel: \\
Tanggal diterima: 18 Desember 2020 \\
Tanggal direvisi: 29 Mei 2021 \\
Tanggal dipublikasi: 26 Juli 2021 \\
\hline
\end{tabular}

Kata kunci:

Kecerdasan Emosional

Kecerdasan Spiritual

Indeks Prestasi

10.32536/jrki.v5i1.137

Keyword :

Emotional Intelligence

Spiritual Intelligence

Achievement Index

\begin{abstract}
ABSTRAK
Latar belakang: Dalam menjalani proses belajar, banyak orang yang beranggapan bahwa untuk meraih prestasi yang baik harus memiliki kecerdasan intelektual (Intelligence Quotient//Q) yang tinggi. Namun, kenyataannya kecerdasan intelektual bukan satu-satunya keberhasilam dalam mengukur prestasi akademik seseorang. Kecerdasan intelektual yang tinggi seyogyanya harus diimbangi dengan kecerdasan emosional dan kecerdasan spiritual. Tujuan penelitian: untuk mengetahui hubungan antara kecerdasan emosional dan kecerdasan spiritual dengan indeks prestasi mahasiswa program studi kebidanan. Metode: Penelitian ini menggunakan pendekatan kuantitatif dengan rancangan studi cross sectional dengan jumlah sampel sebanyak 48 orang. Instrumen yang digunakan dalam penelitian ini adalah pengisian kuesioner dan data indeks prestasi mahasiswa program studi kebidanan. Penelitian ini dilakukan pada bulan Agustus-September tahun 2020. Data dianalisis menggunakan uji chi-square Hasil: hasil dari penelitian ini adalah terdapat hubungan yang signifikan antara kecerdasan emosional dengan $\mathrm{p}$ value 0,001 dan kecerdasan spiritual dengan p-value 0,0001. Simpulan: Ada hubungan antara kecerdasan emosional dan kecerdasan spiritual dengan indeks prestasi mahasiswa program studi kebidanan.
\end{abstract}

Background: in undergoing the learning process, many people assume that to achieve good achievements must have a high intellectual intelligence. However, the reality is that intellectual intelligence is not the only success in measuring a person's academic achievement. High intellectual intelligence should be balanced with emotional intelligence and spiritual intelligence. Objective: The purpose of the study: to find out the relationship between emotional intelligence and spiritual intelligence with the student achievement index of the midwifery study program. Methods: This research uses quantitative approach with cross sectional study design with a sample number of 48 people. The instruments used in this study were filling out questionnaires and student achievement index data of midwifery study programs. This research was conducted in august-september of 2020. Data analyzed using chi-square test results: results from this study are there is a significant relationship between emotional intelligence with $p$-value of 0.001 and spiritual intelligence with $p$ value of 0.0001 . Conclusion: there is a relationship between emotional intelligence and spiritual intelligence with the student achievement index of the midwifery study program.

\section{Pendahuluan}

Indonesia saat ini memasuki era revolusi industri 4.0 dan pendidikan merupakan salah satu aspek yang terpenting dalam era tersebut. Pendidikan dapat menjadi tolak ukur tentang kemajuan suatu bangsa. Pendidikan berperan dalam menciptakan masyarakat yang berkualitas

\footnotetext{
* Korespondensi penulis.

Alamat E-mail: legina@binawan.ac.id
}

dan bertanggung jawab, terutama untuk mempersiapkan individu yang unggul, kreatif, mandiri dan memiliki motivasi serta daya saing dengan bangsa-bangsa dunia (Maraeni, 2017).

Pendidikan tidak dapat dipisahkan dari proses belajar itu sendiri. Belajar menurut Kamus Besar Bahasa Indonesia (KBBI) memiliki arti berusaha memperoleh kepandaian atau ilmu. Sedangkan menurut Winkel (2009) belajar adalah suatu aktivitas mental atau psikis, yang berlangsung dalam interaksi aktif dengan 
lingkungan, yang menghasilkan sejumlah perubahan.

Dalam menjalani proses belajar di institusi pendidikan, banyak orang yang beranggapan bahwa untuk meraih prestasi atau nilai yang tinggi maka harus diimbangi dengan kecerdasan intelektual (Intelligence Quotient/IQ) yang tinggi pula. Kecerdasan intelektual dipandang menjadi satu-satunya ukuran kecerdasan individu. Banyak orang tua yang mendambakan anaknya terlahir dengan IQ yang tinggi.

Kenyataan yang terjadi dalam institusi pendidikan adalah sering ditemukan mahasiswa yang tidak dapat meraih prestasi belajar yang setara dengan kemampuan intelegensinya. Ada mahasiswa yang mempunyai kemampuan intelegensi tinggi, tetapi memperoleh prestasi belajar yang relatif rendah. Namun, ada mahasiswa yang kemampuan intelegensinya rendah dapat meraih prestasi belajar yang relatif tinggi. Itulah sebabnya taraf kecerdasan intelegensi bukan merupakan satu-satunya yang dapat menentukan keberhasilan seseorang (Bahtiar, 2009).

Para ahli psikologi dunia telah memetakan kecerdasan manusia (quotient mapping) yang terdiri dari kecerdasan intelektual, kecerdasan emosional dan kecerdasan spiritual. Ketiga kecerdasan ini merupakan kecerdasan personal yang melekat pada diri individu dan dibutuhkan individu untuk meningkatkan kualitas dirinya sendiri dalam menjalani kehidupan termasuk dalam proses belajar mengajar (Hanafi, 2016).

Menurut Goleman (2008) menyatakan bahwa orang-orang yang murni hanya memiliki kecerdasan akademis tinggi, mereka akan cenderung memiliki rasa gelisah, kritis, cenderung menarik diri dari kehidupan, terkesan dingin dan sulit mengekspresikan kekesalan dan kemarahannya secara tepat. Para ahli psikologi dunia termasuk Daniel Goleman melakukan riset di Amerika yang membuktikan bahwa kecerdasan intelektual hanya menyumbang $20 \%$ terhadap prestasi yang diraih seseorang dan sisanya $80 \%$ ditentukan oleh kecerdasan emosional, kecerdasan sosial dan kecerdasan spiritual (Defila, 2015).

Kebidanan bukanlah ilmu yang hanya mengandalkan mahasiswanya untuk menghafal melainkan lebih kearah pengaplikasian ilmu yang telah didapatkan. Hal ini dikarenakan pendidikan ahli madya bidan merupakan pendidikan vokasi yang lebih mengutamakan keterampilan dibandingkan logika.

Kecerdasan emosional memiliki pengaruh terhadap prestasi belajar mahasiswa. Kecerdasan emosional ini mampu melatih kemampuan untuk mengelola perasaan, kemampuan untuk memotivasi dirinya, mengatur suasana hati serta mampu untuk berempati dan bekerja sama dengan orang lain. Kecerdasan inilah yang mendukung seorang mahasiswa dalam mencapai tujuan dan cita-citanya (Rachmi, 2010).

Bila taraf kecerdasan emosional rendah dibandingkan dengan taraf kecerdasan intelektualnya individu berpotensi untuk bersikap keras kepala, sulit bersosialisasi, mudah frustasi, tidak mudah percaya dengan orang lain, tidak peka dengan kondisi lingkungan dan cenderung putus asa bila mengalami stress (Goleman, 2008).

Nugroho (2004) dalam Ananto 2008 menyatakan bahwa pembelajaran yang hanya berpusat pada kecerdasan intelektual tanpa menyeimbangkan sisi spiritual akan menghasilkan generasi yang mudah putus asa dan depresi. Kurangnya kecerdasan spiritual dalam diri seorang mahasiswa akan mengakibatkan mahasiswa kurang termotivasi untuk belajar dan sulit untuk berkonsentrasi, sehingga mahasiswa akan sulit untuk memahami suatu mata kuliah.

Individu yang hanya mengejar prestasi berupa nilai dan mengabaikan sisi spiritual akan melakukan berbagai cara untuk mendapatkan nilai yang bagus dan mereka akan cenderung untuk bersikap tidak jujur. Oleh karena ini, kecerdasan spiritual mampu mendorong mahaisswa untuk mencapai keberhasilan dalam proses belajarnya karena, kecerdasan spiritual merupakan dasar untuk mendorong berfungsinya kecerdasan intelektual (IQ) dan kecerdasan emosional (EQ).

Tanis Helliwel dalam Wahid (2006) mengatakan bahawa dengan memiliki kecerdasan spiritual yang tinggi, maka tingkat kesuksesan seseorang akan meningkat pada masa yang akan datang. Berdasarkan uraian diatas maka penulis tertarik untuk melakukan penelitian dengan judul "Hubungan Kecerdasan Emosional Dan Kecerdasan Spiritual Dengan Indeks Prestasi Mahasiswa Program Studi Kebidanan" 


\section{Metode penelitian}

Penelitian ini menggunakan pendekatan kuantitatif dengan rancangan studi cross sectional dengan jumlah populasi sebanyak 48 orang sedangkan sampel penelitian menggunakan teknik total sampling yaitu sebanyak 48 orang. Instrumen yang digunakan dalam penelitian ini adalah pengisian kuesioner dan data indeks prestasi mahasiswa program studi kebidanan. Penelitian ini dilakukan pada bulan Agustus-September tahun 2020 di Universitas Binawan. Data yang dikumpulkan kemudian dilakukan analisis menggunakan uji chisquare.

\section{Hasil dan Pembahasan}

\section{Analisa Univariat}

Tabel 1. Distribusi Frekuensi Indeks Prestasi Semester Mahasiswa

\begin{tabular}{lll}
\hline Indeks Prestasi Mahasiswa & (N) & (\%) \\
\hline Baik $(\geq 3,00)$ & 23 & 47,9 \\
Kurang Baik $(<3,00)$ & 25 & 52,1 \\
TOTAL & $\mathbf{4 8}$ & $\mathbf{5 2 , 1}$ \\
\hline
\end{tabular}

Berdasarkan tabel 1 didapati hasil bahwa indeks prestasi mahasiswa kebidanan didominasi oleh indeks prestasi kurang baik sebesar 52, $1 \%$ dan indeks prestasi baik diperoleh mahasiswa kebidanan dengan persentase $47,9 \%$.

Dalam penelitian ini, peneliti membagi dua kategori indeks prestasi semester yaitu indeks prestasi baik dan indeks prestasi kurang baik. Pada semester III terdapat mata kuliah Asuhan Kebidanan II (Persalinan), Asuhan Kebidanan III (Nifas) dan Asuhan Neonatus Bayi dan Balita, IImu Kesehatan Anak dan Ginekologi yang merupakan kompetensi inti yang harus dicapai oleh seorang bidan sehingga sebagian besar mahasiswa merasa mata kuliah tersebut sulit dibandingkan dengan semester sebelumnya yang mengakibatkan indeks prestasi semester mahasiswa menurun.

Tabel 2. Distribusi Frekuensi Klasifikasi Kecerdasan Emosional Mahasiswa

\begin{tabular}{llc}
\hline \multicolumn{1}{c}{ Kecerdasan Emosional } & (N) & (\%) \\
\hline Baik $(\geq 76 \%)$ & 20 & 41,7 \\
Kurang Baik $(<75 \%)$ & 28 & 58,3 \\
Total & $\mathbf{4 8}$ & $\mathbf{1 0 0}$ \\
\hline
\end{tabular}

Berdasarkan tabel 2 didapati hasil bahwa kecerdasan emosional mahasiswa kebidanan didominasi oleh kecerdasan emosional yang kurang baik yaitu sebesar 58,3 \% dan sisanya sebanyak $41,7 \%$ mempunyai kecerdasan emosional yang baik.

Tabel 3. Distribusi Frekuensi Klasifikasi Kecerdasan Spiritual Mahasiswa

\begin{tabular}{lcc}
\hline Kecerdasan Spiritual & (N) & (\%) \\
\hline Baik $(\geq 76 \%)$ & 26 & 54,2 \\
Kurang Baik $(<75 \%)$ & 22 & 45,8 \\
Total & $\mathbf{4 8}$ & $\mathbf{1 0 0}$ \\
& & \\
\hline
\end{tabular}

Berdasarkan tabel 3 didapati hasil bahwa kecerdasan spiritual mahasiswa kebidanan didominasi oleh kecerdasan spiritual yang baik yaitu sebesar sebanyak 54,2 \% mahasiswa kebidanan mempunyai kecerdasan spiritual yang baik dan sisanya memiliki kecerdasan spiritual yang kurang baik sebesar $45,8 \%$.

\section{Analisa Bivariat}

Tabel 4. Hubungan Kecerdasan Emosional dengan Indeks Prestasi Mahasiswa

\begin{tabular}{|c|c|c|c|c|c|c|}
\hline \multirow{3}{*}{$\begin{array}{c}\text { Kecerdasan } \\
\text { Emosional }\end{array}$} & \multicolumn{4}{|c|}{ INDEKS PRESTASI } & \multicolumn{2}{|c|}{ TOTAL } \\
\hline & \multicolumn{2}{|c|}{ BAIK } & \multicolumn{2}{|c|}{ KURANG } & \multirow[b]{2}{*}{$\mathbf{N}$} & \multirow[b]{2}{*}{$\%$} \\
\hline & $\mathbf{N}$ & $\%$ & $\mathbf{N}$ & $\%$ & & \\
\hline Baik & 16 & 33,3 & 4 & 8,3 & 20 & 41,6 \\
\hline Kurang Baik & 7 & 14,6 & 21 & 43,8 & 28 & 58,4 \\
\hline TOTAL & 23 & 47,9 & 25 & 52,1 & 48 & 100 \\
\hline P-Value & \multicolumn{6}{|c|}{0,001} \\
\hline OR & \multicolumn{6}{|c|}{12,000} \\
\hline
\end{tabular}

Berdasarkan tabel 4 terlihat bahwa responden yang memiliki kecerdasan emosional baik mempunyai persentase lebih banyak yang memiliki indeks prestasi baik yaitu sebesar $33 \%$, sedangkan responden yang memiliki kecerdasan emosional kurang baik hanya ada sebesar 14,6\% yang memiliki indeks prestasi yang baik. Hasil uji statistic diperoleh $p$-value 0,001 yang berarti terdapat hubungan yang signifikan antara kecedasan emosinal dengan indeks prestasi mahasiswa.

Hasil analisis lainnya diperoleh Odd ratio (OR) sebesar 12,000 artinya mahasiswa yang memiliki kecerdasan emosional baik berpeluang untuk mendapatkan indeks prestasi yang baik 12,000 kali dibandingkan dengan mahasiswa yang memiliki kecerdasan emosional yang kurang baik. 
Menurut Goleman (2008) menyatakan bahwa kecerdasan emosional memiliki peran penting untuk mencapai kesuksesan di institusi pendidikan, maupun dalam berkomunikasi di dalam masyarakat. Kecerdasan emosional mencakup kemampuan yang berbeda-beda tetapi slaing melengkapi dengan kecerdasan akademik yaitu kemampuan kognitif murni yang diukur dengan IQ.

Hasil penelitian ini sesuai dengan penelitian yang telah dilakukan oleh Rampisela pada tahun 2017 yang menyatakan bahwa terdapat hubungan yang signifikan antara kecerdasan emosional dengan prestasi belajar dimana hasil yang diperoleh adalah $p$-value 0,011 . Penelitian lain juga menyebutkan sebesar $26,3 \%$ responden yang memiliki kecerdasan emosional baik (kategori sedang) memiliki prestasi belajar sangat memuaskan (Rizkiyah, 2014).

Menurut Putri (2011) menjelaskan bahwa kecerdasan emosi memiliki peran yang sangat penting untuk mencapai puncak prestasi. Kemampuan mengelola emosi memiliki arti bahwa mahasiswa sudah siap secara fisik dan psikis untuk menerima pelajaran. Semangat dan ketekunan belajar merupakan faktor yang mendorong seseorang untuk mencapai puncak prestasi.

Komponen kecerdasan emosional salah satunya adalah motivasi yang merupakan hasrat untuk membangkitkan semangat untuk mencapai prestasi akademik yang lebih baik. Dorongan berprestasi untuk menjadi lebih baik akan tertanam pada diri individu yang memiliki kecerdasan emosional yang stabil (Goleman, 2008). Motivasi merupakan unsur terpenting dalam kecerdasan emosional. Hal ini dikarenakan motivasi dapat mendorong individu untuk terlibat aktif dalam proses pembelajaran, mendorong individu untuk terus belajar dan dapat menciptakan suasana belajar yang menyenangkan sehingga dapat meningkatkan prestasi akademik (Yahaya, dkk, 2012).

Maka dari itu mahasiswa yang memiliki tingkat kecerdasan emosional yang baik lebih dapat memotivasi dirinya sendiri untuk memperoleh indeks prestasi belajar yang baik begitu pula sebaliknya, jika mahasiswa memiliki kecerdasan emosional yang kurang baik maka motivasi dirinya untuk berprestasi juga akan menurun.
Tabel 5. Hubungan Kecerdasan Spiritual dengan Indeks Prestasi Mahasiswa

\begin{tabular}{cccccccc}
\hline \multirow{2}{*}{$\begin{array}{c}\text { Kecerdasan } \\
\text { Spiritual }\end{array}$} & \multicolumn{4}{c}{ Indeks Prestasi } & \multicolumn{2}{c}{ TotaL } \\
\cline { 2 - 5 } & \multicolumn{2}{c}{ Baik } & \multicolumn{3}{c}{ Kurang } & & \\
& N & $\%$ & N & \% & N & \% \\
\hline Baik & 20 & 41, & 6 & 12,5 & 26 & 54,2 \\
Kurang Baik & 3 & 6,2 & 19 & 39,6 & 22 & 45,8 \\
Total & $\mathbf{2 3}$ & $\mathbf{4 7 ,}$ & $\mathbf{2 5}$ & $\mathbf{5 2 , 1}$ & $\mathbf{4 8}$ & $\mathbf{1 0 0}$ \\
P-Value & & $\mathbf{9}$ & & & & \\
OR & & & $\mathbf{0 , 0 0 0 1}$ & & \\
\hline
\end{tabular}

Berdasarkan tabel 5 terlihat bahwa responden yang memiliki kecerdasan spiritual baik mempunyai persentase lebih banyak yang memiliki indeks prestasi baik yaitu sebesar 41,7\%, sedangkan responden yang memiliki kecerdasan spiritual kurang baik hanya ada sebesar $6,2 \%$ yang memiliki indeks prestasi yang baik. Hasil uji statistik diperoleh $p$-value 0,0001 yang berarti terdapat hubungan yang signifikan antara kecedasan emosional dengan indeks prestasi mahasiswa.

Hasil analisis lainnya diperoleh Odd ratio (OR) sebesar 21,111 artinya mahasiswa yang memiliki kecerdasan spiritual baik berpeluang untuk mendapatkan indeks prestasi yang baik 21,111 kali dibandingkan dengan mahasiswa yang memiliki kecerdasan spiritual yang kurang baik.

Hasil penelitian ini sejalan dengan penelitian yang telah dilakukan oleh Randa, dkk (2016) yang menyatakan bahwa terdapat hubungan yang signifikan antara kecerdasan spiritual dengan indeks prestasi kumulatif mahasiswa dengan $p$ value 0,0001 . Penelitian lainnya yang dilakukan oleh Miterianifa (2015) juga menyebutkan bahwa terdapat hubungan yang positif antara kecerdasan spiritual dengan hasil belajar mahasiswa program studi pendidikan kimia.

Hal ini pun sejalan dengan teori bahwa kecerdasan spiritual yang tinggi akan memotivasi diri sendiri untuk giat belajar karena mahasiswa yang memiliki kecerdasan spiritual yang tinggi memiliki rasa ingin tahu yang tinggi, sehingga memiliki motivasi untuk selalu belajar dan memiliki kreativitas tinggi (Rachmi, 2010). Kecerdasan spiritual merupakan salah satu bentuk kecerdasan yang akan menjadi pondasi utama untuk lebih mengefektifkan kecedasan intelektual dan kecerdasan emosional (Hapsari, 2010). 


\begin{abstract}
Zohar dan Marshall menjelaskan bahwa spiritualitas tidak harus dikaitkan dengan kedekatan seseorang dengan aspek ketuhanan. Kecerdasan spiritual lebih berkaitan dengan pencerahan jiwa. Individu yang memiliki kecerdasan spiritual tinggi mampu memaknai hidup dengan memberi makna positif pada setiap peristiwa, masalah, bahkan penderitaan yang diamalinya. Dengan memberi makna yang positif akan mampu membangkitkan jiwa dan melakukan perbuatan dan tindakan yang positif
\end{abstract}

\section{Simpulan}

Kesimpulan yang dapat ditarik dari penelitian yang telah dilakukan bahwa kecerdasan emosional ( $p$-value 0,001) dan kecerdasan spiritual ( $p$-value 0,0001$)$ juga memiliki hubungan dengan prestasi mahasiswa dalam hal ini diukur dari indeks prestasi semester mahasiswa program studi kebidanan.

\section{Ucapan terima kasih}

Ucapan terima kasih penulis sampaikan kepada semua pihak yang telah membantu dalam kegiatan penelitian ini, terutama kepada Universitas Binawan yang telah memberikan dukungan kepada seluruh dosen dalam mengamalkan Tridarma perguruan tinggi khususnya dibidang penelitian.

\section{Daftar Pustaka}

Ananto, Hersan (2008). Pengaruh Kecerdasan Emosional dan Kecerdasan Spiritual terhadap Tingkat Pemahaman Akuntansi. Surakarta. Fakultas Ekonomi Universitas Muhammadiyah

Bahtiar (2009). Hubungan Antara Kecerdasan Emosional Dengan Prestasi Belajar Siswa Kelas II SMP Negeri 2 Mataram. Jurnal Pemikiran Alternatif Pendidikan. Vol. 14(2):254-268

Defila, dkk (2015). Hubungan Kecerdasan Emosional Dengan Hasil Belajar IPA Siswa SMP Negeri 1 Palu. Jurnal Pendidikan Fisika Tadulako. Vol. 2 No. 2

Goleman, Daniel (2008). Emotional Intelligence. Jakarta: PT. Gramedia Pustaka Utama.
Hanafi. Z \& Noor. F (2016). Relationship Between Emotional Intellegence and Academic Achievement in Emerging Adults: $A$ Systematic Review. International Journal of Academic Research in Business and Socil Sciences. Vol. 6. NO. 6:268-290

Hapsari, P.R (2010). Hubungan Antara Kecerdasan Emosional dengan Motivasi Belajar Pada Mahasiswa D IV Kebidanan Fakultas Kedokteran Universitas Sebelas Maret. Surakarta. Fakultas Kedokteran

Maraeni, K.M (2017). Hubungan Kecerdasan Emosional Terhadap Hasil Belajar Akidah Akhlak di Madrasah Khazanah Kebajikan Pondok Cabe Tanggerang Selatan . Jakarta: Fakultas IImu Tarbiyah dan Keguruan

Miterianifa (2015). Hubungan Antara Spiritual Quotient Mahasiswa Dengan Hasil Belajar Strategi Pembelajaran Kimia Yang Terintegrasi Dengan Nilai-Nilai Islam. POTENSIA: Jurnal Kependidikan Islam. JuliDesember 2015. Vol. 1 No. 2

Putri, N. Eka Sri Kadek (2011). Hubungan Kecerdasan Emosi dan Kesiapan Belajar Dengan Prestasi Belajar Pada Mata Kuliah Askeb Ibu I Mahasiswa Semester II AKBID Mitra Husada Karang Anyar. Surakarta. Magister Kedokteran Keluarga

Rachmi, Filia (2010). Pengaruh Kecerdasan Emosional, Kecerdasan Spiritual Dengan Prestasi Belajar Terhadap Tingkat Pemahaman Akutansi. Semarang

Rampisela, D.I (2017). Hubungan Kecerdasan Emosional dan Kecerdasan Spiritual Dengan prestasi Belajar Siswa di SMP Katolikst Fransiscus Pineleng. E-journal Keperawatan. Februari 2017; Vol.5 No. 1

Randa, G., Syafri, A (2016)., Zawirman, Z. Hubungan Kecerdasan Spiritual Mahasiswa Dengan Tingkat Indeks Prestasi Kumulatif (IPK) di Jurusan Geografi Universitas Negeri Padang. Journal Of Geography.

Rizkiyah, A (2017). Hubungan Kecerdasan Emosional dan Kecerdasan Spiritual Dengan Prestasi Belajar Mahasiswa D4 Bidan Pendidik Semester 4 Di Universitas 'Aisiyah Yogyakarta Yogyakarta. Fakultas IImu Kesehatan 
Wahid, A (2006). SQ Nabi Aplikasi Strategi dan Model Kecerdasan Spiritual (SQ) Rasulullah di Masa Kini. Yogyakarta: Ircisod

Winkel, WS (2009). Psikologi Pengajaran. Jakarta
Yahaya, dkk (2012). The Impact of Emotional Intelligence Element on Academic Achivement. Archives Des Sciences. April 2012. Vol 65 No.2 